\title{
CONCENTRATION OF JURISDICTION - IS FUNCTIONALITY OF JUDICIARY BECOMING AN OBSTACLE TO ACCESS TO JUSTICE?
}

\author{
Mirela Župan, PhD, Associate Professor \\ Josip Juraj Strossmayer University of Osijek, Faculty of Law \\ Stjepana Radića 13, Osijek, Croatia \\ mzupan@pravos.hr
}

\author{
Paula Poretti, PhD, Assistant Professor \\ Josip Juraj Strossmayer University of Osijek, Faculty of Law \\ Stjepana Radića 13, Osijek, Croatia \\ paula.poretti@pravos.hr
}

\begin{abstract}
Matters of jurisdiction seem to be among aspects of judicial cooperation in civil and commercial matters in which so far most regulatory activity of the European union (hereinafter: EU) has been undertaken. Upon close examination of the rules on jurisdiction of courts in civil and commercial matters in the existing legal framework at EU level, it becomes obvious that they contain the same principle of territoriality. At the same time, in the course of modernization both at the national and EU level it seems that the principle of functionality is becoming more dominant. A question whether it is justified to depart from rules on jurisdiction based on the principle of territoriality and confer jurisdiction on a court other than that of the defendant's domicile based on the principle of functionality in a cross-border case has arisen recently in joined cases C-400/13 and C-408/13. Within the context of a rather ambiguous view the CJEU took in its decision in the aforementioned cases, the paper examines if enhancing functionality through concentration of jurisdiction will eventually become an advantage or obstacle to access to justice. The analysis includes presentation and comparison of provisions on jurisdiction in cross-border cases based on the principle of territoriality and functionality respectively in several EU legal instruments regulating private international law and civil procedure matters. The paper attempts to draw attention to models of achieving procedural efficiency in different fields of EU's activity, such as enhancing consumer protection or introducing cross-border collective redress.
\end{abstract}

Keywords: principle of territoriality, principle of functionality, access to justice, joined cases $C-400 / 13$ and $C-408 / 13$, concentration of jurisdiction 


\section{INTRODUCTION}

Matters of jurisdiction seem to be among the fields of judicial cooperation in civil and commercial matters in which so far most regulatory activity of the European union (hereinafter: EU) has been undertaken. Namely, along with the number of national legal systems of Member States, the fact that there is a great diversity among national rules which distinguish competence of national courts and other bodies and prescribe competence of national courts in cross-border cases (compétence internationale ${ }^{1}$ additionally emphasizes the challenge and complexity of addressing the question of jurisdiction at EU level. At the national level, traditional approach to determination of jurisdiction is based on the principle of territoriality. According to this principle court is entrusted with jurisdiction based on a connection between the parties or the subject matter of the dispute and the territory of the court. ${ }^{2}$ Along with the general rule on jurisdiction based on the habitual residence of the defendant, special rules on jurisdiction determine jurisdiction of a certain court by taking into account the circumstances of the case and significant social interests.

National rules on jurisdiction in cross-border cases also determine jurisdiction based on the principle of territoriality. Hence, according to the general rule Member State court has jurisdiction in a cross-border case involving a defendant domiciled in a Member State.

When observing the rules on jurisdiction of courts in civil and commercial matters in the existing legal framework at EU level it is obvious that they contain the same principle of territoriality. The cornerstone of the rules of jurisdiction within the Council Regulation (EC) No 44/2001 of 22 December 2000 on jurisdiction and the recognition and enforcement of judgments in civil and commercial matters $^{3}$ (hereinafter: Brussels I Regulation) as well as Regulation (EU) 1215/2012 of the European Parliament and of the Council of 12 December 2012 on jurisdiction and the recognition and enforcement of judgments in civil and commercial matters $^{4}$ (hereinafter: Brussels I bis Regulation) is the principle that jurisdiction is

Triva, S.; Dika, M. Gradansko parnično procesno pravo, Narodne novine, 2004, p. 259

Ibid., p. 271

Council Regulation (EC) No 44/2001 of 22 December 2000 on jurisdiction and the recognition and enforcement of judgments in civil and commercial matters, OJ L 12, 16.1.2001. Recital (15) and Art 4 (1986) of the Preamble Brussels Convention and Brussels I Regulation, Art 2

4 Regulation (EU) 1215/2012 of the European Parliament and of the Council of 12 December 2012 on jurisdiction and the recognition and enforcement of judgments in civil and commercial matters, $\mathbf{O J} \mathbf{L}$ 351, 20.12.2012., Art 4 
generally based on the defendant's domicile. ${ }^{5}$ It is considered to be a guarantee of protection of defendants and weaker parties in legal proceedings.

The relevance of adapting the rules on jurisdiction in order to ensure that a dominant party will not gain advantage in the proceedings is confirmed in the Brussels I bis Regulation. Namely, in the Brussels I bis Regulation the territorial (or formal) scope of application in disputes involving weaker parties is extended and a number of new provisions to ensure a greater degree of protection for weaker parties are inserted. However, the protection of a weaker party does not seem to be ensured in the same manner and to the same extent in other EU instruments that unify certain rules of civil procedure and enhance the mutual recognition of judgments. ${ }^{6}$ In example, Regulation (EC) No 1896/2006 of the European Parliament and of the Council of 12 December 2006 creating a European order for payment procedure ${ }^{7}$ (hereinafter: Regulation No 1896/2006), Regulation (EC) No 861/2007 of the European Parliament and of the Council of 11 July 2007 establishing a European small claims procedure ${ }^{8}$ (hereinafter: Regulation No 861/2007) and Regulation (EC) No 805/2004 of the European Parliament and of the Council of 21 April 2004 creating a European Enforcement Order for uncontested claims ${ }^{9}$ (hereinafter: Regulation No 805/2004) as legislative instruments which created unified European civil procedures and contributed to gradual abolishment of the exequatur, contain some specific provisions on jurisdiction, which differ from those provided under Brussels I bis Regulation.

At the same time, in the course of modernization both at the national and EU level it seems that the principle of functionality is becoming more dominant. Difficulties in administration of justice and obstacles to securing a certain level of quality of a court decision in terms of length of the procedure and lack of managerial skills of the judge are present in national legal systems of Member States. Efforts made

Dickinson, A.; Lein, E. The Brussels I Regulation Recast, Oxford University Press, 2015, p. 21

6 See Lazić, V. Procedural Position of a 'Weaker Party in the Regulation Brussels I bis, in: Lazić, V.; Stuij, S. (eds.), Brussels I bis Regulation. Changess and Challenges of the Renewed Procedural Scheme, Springer, 2017, p. 115

7 Regulation (EC) No 1896/2006 of the European Parliament and of the Council of 12 December 2006 creating a European order for payment procedure, [2006] OJ L 399/1

8 Regulation (EC) No 861/2007of the European Parliament and of the Council of 11 July 2007 establishing a European small claims procedure, [2007] OJ L 199/1. The Regulation 861/2007 was subsequently amended by the Regulation (EU) 2015/2421 of the European Parliament and of the Council of 16 December 2015 amending Regulation (EC) No 861/2007 establishing a European Small Claims Procedure and Regulation (EC) No 1896/2006 creating a European order for payment procedure, [2015] OJ L 341/1

9 Regulation (EC) No 805/2004 of the European Parliament and of the Council of 21 April 2004 creating a European Enforcement Order for uncontested claims [2004] OJ L 143 
in order to remove them include changes in organization of judiciary, including rules on concentration of jurisdiction.

A question whether it is justified to depart from rules on jurisdiction based on the principle of territoriality and confer jurisdiction on a court other than that of the defendant's domicile based on the principle of functionality in a cross-border case has arisen recently in joined cases C-400/13 and C-408/13 Sophia Marie Nicole Sanders $v$ David Verhaegen and Barbara Huber $v$ Manfred Huber ${ }^{10}$. Namely, requests for preliminary ruling were made from the Amtsgericht Düsseldorf and the Amtsgericht Karlsruhe (Germany) which concern the question whether according to the interpretation of the Article 3(a) and (b) of Council Regulation (EC) No 4/2009 of 18 December 2008 on jurisdiction, applicable law, recognition and enforcement of decisions and cooperation in matters relating to maintenance obligations ${ }^{11}$ (hereinafter: Maintenance Regulation) Paragraph 28(1) of [the AUG] is contrary to Article 3(a) and (b) of Maintenance Regulation.

Another question has arisen in regard to interpretation of Article 11(7) and (8) of the Brussels II bis Regulation in case C498/14 PPU David Bradbrooke v Anna Aleksandrowicz ${ }^{12}$. In the urgent preliminary ruling procedure Cour d'appel de Bruxelles (Belgium) requested the CJEU to examine whether national procedural rules providing for specialisation of courts according to the principle of functionality in situations of parental child abduction with respect to the procedure provided for in those [provisions] even where a court or tribunal has already been seized of proceedings concerning the substance of parental responsibility in relation to the child are contrary to provisions of Article 11(7) and (8) of the Council Regulation (EC) No 2201/2003 of 27 November 2003 concerning jurisdiction and the recognition and enforcement of judgments in matrimonial matters and the matters of parental responsibility, repealing Regulation (EC) No 1347/200013 (hereinafter: Brussels II bis Regulation).

10 CJEU, Joined cases C-400/13 and C-408/13, Sophia Marie Nicole Sanders v David Verhaegen and Barbara Huber v Manfred Huber, ECLI:EU:C:2014:2461, 18 December 2014

11 Regulation (EC) No 4/2009 of 18 December 2008 on jurisdiction, applicable law, recognition and enforcement of decisions and cooperation in matters relating to maintenance obligations, OJ L 7, 10.1.2009

12 CJEU, C498/14 PPU David Bradbrooke v Anna Aleksandrowicz, ECLI:EU:C:2015:3, 9 January 2015

13 Council Regulation (EC) No 2201/2003 of 27 November 2003 concerning jurisdiction and the recognition and enforcement of judgments in matrimonial matters and the matters of parental responsibility, repealing Regulation (EC) No 1347/2000, OJ L 338/1, 23.12.2003 
In case C498/16 Maximilian Schrems v Facebook Ireland Limited ${ }^{14}$ Supreme Court of Austria (Oberster Gerichtshof) also referred an interesting question for preliminary ruling concerning concentration of jurisdiction, but here in consumer disputes, under Brussels I Regulation. The Supreme Court of Austria was uncertain whether Article 16 of the Brussels I Regulation is to be interpreted as meaning that a consumer in a Member State can also invoke at the same time as his own claims arising from a consumer supply at the claimant's place of jurisdiction the claims of others consumers on the same subject who are domiciled (a) in the same Member State, (b) in another Member State, or (c) in a non-member State, if the claims assigned to him arise from consumer supplies involving the same defendant in the same legal context and if the assignment is not part of a professional or trade activity of the applicant, but rather serves to ensure the joint enforcement of claims.'

Within the context of these several interesting judgments delivered by the CJEU, the paper examines if enhancing functionality through concentration of jurisdiction will eventually become an advantage or obstacle to access to justice. The analysis further includes a presentation and a comparison of provisions on jurisdiction in cross-border cases based on the principle of territoriality and functionality respectively in several EU legal instruments regulating private international law and civil procedure matters.

\section{RELEVANT FACTS OF THE CASES}

\subsection{Joined cases $\mathrm{C}-400 / 13$ and $\mathrm{C}-408 / 13$}

In joined cases C-400/13 and C-408/13 requests for preliminary ruling were made from the Amtsgericht Düsseldorf and the Amtsgericht Karlsruhe (Germany) whether Paragraph 28(1) of the AUG is contrary to Article 3(a) and (b) of Maintenance Regulation. In order to understand the cases at hand as well as the decision of the CJEU it is necessary to state the facts of the cases.

These cases have arisen in two disputes relating to claims for maintenance payments, first, between Miss Sanders, a minor represented by her mother, Ms Sanders, and Mr Verhaegen, Miss Sanders' father and, second, between Mrs Huber and her husband, Mr Huber, from whom Mrs Huber is separated. Those claims were brought, respectively, before the Amtsgericht (local court of first instance) of the German towns in which the maintenance creditors concerned habitually reside. Amtsgericht Düsseldorf and the Amtsgericht Karlsruhe, according to a provision implementing in German law the cases to which Article 3(a) and (b) of Mainte-

14 CJEU, Case C-498/16, Maximilian Schrems v Facebook Ireland Limited, ECLI:EU:C:2018:37, 25 January 2018 
nance Regulation refers, declined jurisdiction in favour of the Amtsgericht in the town of the seat of the Oberlandesgericht (Higher Regional Court) in whose area of jurisdiction those applicants reside.

In its decision the CJEU took the view that Article 3(b) of Maintenance Regulation must be interpreted as precluding national legislation such as that at issue in the main proceedings which establishes centralisation of judicial jurisdiction in matters relating to cross-border maintenance obligations in favour of a first instance court which has jurisdiction for the seat of the appeal court, except where that rule helps to achieve the objective of a proper administration of justice and protects the interests of maintenance creditors while promoting the effective recovery of such claims, which is, however, a matter for the referring courts to verify.

By putting forward the argument that national legislation which departs from the rules on jurisdiction based on the principle of territoriality and confers jurisdiction on a court other than that of the defendant's domicile is not contrary to Article 3 (b) of Maintenance Regulation where that rule helps to achieve the objective of a proper administration of justice and protects the interests of maintenance creditors while promoting the effective recovery of such claims, in its decision, the CJEU confirms that in the interpretation of national legislation such as that at issue, it is necessary to observe the objectives and scheme of the EU Regulation which prescribes rules on cross-border matters at issue.

Namely, in the Recital (15) of Preamble of the Maintenance Regulation reference is made to preservation of the interests of maintenance creditors and promotion of the proper administration of justice within EU. According to the Opinion of Advocate General these general aims form the basis for the rules of jurisdiction laid down by Maintenance Regulation. ${ }^{15}$ But as the Advocate General further emphasizes at point 69 that objective must be understood not only as the most rationalised judicial organisation possible but also from the point of view of the interests of the litigant, whether applicant or defendant, in gaining, inter alia, easy access to justice and foreseeability of jurisdiction, owing to a close link between the court and the dispute.

\subsection{Case C498/14 PPU David Bradbrooke v Anna Aleksandrowicz}

In case C498/14 PPU David Bradbrooke v Anna Aleksandrowicz, at the request of the Cour d'appel de Bruxelles (Belgium), the CJEU examined whether national procedural rules providing for specialisation of courts in situations of parental

15 See also Advocate General opinion, p. 40 
child abduction with respect to the procedure provided for in those [provisions] even where a court or tribunal has already been seized of proceedings concerning the substance of parental responsibility in relation to the child are contrary to provisions of Article 11(7) and (8) of the Brussels II bis Regulation.

In the case at hand, the request for urgent preliminary ruling has been made by the Cour d'appel de Bruxelles in proceedings between Mr Bradbrooke and Ms Aleksandrowicz concerning parental responsibility for their son Antoni, who has been retained in Poland by Ms Aleksandrowicz.

Mr Bradbook lodged the first application on 18 October 2013 before the tribunal de la jeunesse de Bruxelles (the court for young persons in Brussels) seeking a ruling on, inter alia, how parental authority over the child was to be exercised and accommodation rights with respect to the child. Additionally, on 23 October 2013, the father brought an action before the judge hearing applications for interim measures claiming provisionally and as a matter of urgency that secondary accommodation rights in respect of the child should be granted to him. ${ }^{16}$ The mother challenged the international jurisdiction of the Belgian courts, seeking the application of Article 15 of the Regulation and the transfer of the case to the Polish courts, which are particularly connected to the child's situation, since the child is residing in Poland and has in the interim been registered in a nursery school.

On 26 March 2014, the tribunal de la jeunesse de Bruxelles, confirmed its jurisdiction, held that parental authority should be exercised jointly by the parents, granted to the mother primary accommodation rights in respect of the child and temporarily granted to the father secondary accommodation rights on alternate week-ends, it being his responsibility to travel to Poland. The father brought an appeal against that judgment before the cour d'appel de Bruxelles, seeking, principally, the exclusive exercise of parental authority and primary accommodation rights in respect of the child. ${ }^{17}$ Although the district court of Płońsk (Poland) found that the child had been wrongfully removed by his mother and that the child had been habitually resident in Belgium before the removal, it decided to issue an order on the non-return of the child on the basis of Article 13b of the

16 He subsequently amended his claims before the judge hearing applications for interim measures and before the tribunal de la jeunesse de Bruxelles and sought, inter alia, the exclusive exercise of parental authority, primary accommodation rights in respect of the child and an order prohibiting the mother from leaving Belgian territory with the child. By order of 19 December 2013 the judge hearing applications for interim measures declared that he had jurisdiction and, provisionally and in the interests of urgency, upheld the father's claims

17 At the same as bringing proceedings on the substance before the Belgian courts, on 20 November 2013 the father brought an application before the Belgian central authority for the return forthwith of the child to Belgium under the return procedure established by the 1980 Hague Convention 
Convention of 25 October 1980 on the Civil Aspects of International Child Abduction $^{18}$ (hereinafter: 1980 Hague Convention).

The father then lodged submissions to the tribunal de première instance francophone de Bruxelles, which court had jurisdiction, in accordance with Article $1322 i$ of the Judicial Code ${ }^{19}$ to examine the question of custody with respect to the child, pursuant to Article 11(6) and (7) of the Regulation. ${ }^{20}$ After the entry into force of the 2013 legislation, the case was reallocated to the tribunal de la famille de Bruxelles [the family court in Brussels]. The cour d'appel de Bruxelles declared that the Belgian court had international jurisdiction to rule on the substance of questions relating to parental responsibility. However, since an action based on Article 11(6) and (7) of the Regulation had in the interim been brought before the tribunal de première instance francophone de Bruxelles, the cour d'appel stayed its ruling on the substance of the dispute. During this period, the father was not able to exercise the right of access since the mother refused to disclose information on the child's residence. The Polish courts, after finding that the Belgian court had been first seized and had declared that they had international jurisdiction, held that they had no jurisdiction in the matter.

By final judgment delivered on 8 October 2014, the tribunal de la famille de Bruxelles referred the case to the cour d'appel de Bruxelles, on the ground that the Belgian courts had been seized by the father before the wrongful removal of the child for the purposes of Art 11(7) of the Regulation and that the substantive proceedings were pending before the cour d'appel. The cour d'appel de Bruxelles considers that, under Belgian law, it cannot regard itself as seized of the procedure set out in Art 11(6) to (8) of the Regulation by the referral judgment delivered by the tribunal de la famille de Bruxelles on 8 October 2014. The cour d'appel considers that it could be seized of that procedure only by an appeal being brought by one of the parties against that judgment. Hence, the cour d'appel de Bruxelles referred the question for a preliminary ruling to the CJEU.

The CJEU found that jurisdiction of a specialised court in a Member State to examine questions of return or custody with respect to a child in the context of the procedure set out in those provisions, even where proceedings on the substance

18 Convention of 25 October 1980 on the Civil Aspects of International Child Abduction, concluded 25 October 1980

19 In the version of the Judicial Code applicable prior to the entry into force of the loi du 30 juillet 2013 portant création du tribunal de la famille [law of 30 July 2013 on the creation of a family court]

20 Under Article $1322 i$ of the Judicial Code, the bringing of an action before that court entails that proceedings commenced before courts and tribunals seized of a dispute concerning parental responsibility or a related dispute are to be stayed 
of parental responsibility with respect to the child have already, separately, been brought before a court or tribunal is not contrary to Article 11(7) and (8) of the Brussels II bis Regulation.

\subsection{Case C498/16 Maximilian Schrems v Facebook Ireland Limited,}

The request has been made in proceedings between Mr Maximilian Schrems, who is domiciled in Austria, and Facebook Ireland Limited, which has its registered office in Ireland, concerning applications seeking declarations and an injunction, disclosure, production of accounts and payment in the amount of EUR 4000 in respect of private Facebook accounts of both Mr Schrems and seven other persons who assigned to him their claims relating to those accounts. Mr Schrems has been a user of the social network Facebook since 2008. ${ }^{21}$

From August 2011, Mr Schrems lodged before the Irish Data Protection Commissioner 23 complaints against Facebook Ireland, one of which gave rise to a reference for a preliminary ruling before the Court.

Mr Schrems brought an action before the Landesgericht für Zivilrechtssachen Wien (Regional Civil Court, Vienna, Austria), seeking, first, comprehensive declarations of the status of the defendant in the main proceedings as a mere service provider and of its duty to comply with instructions or of its status as an employer, where the processing of data is carried out for its own purposes, the invalidity of contract terms relating to conditions of use, second, an injunction prohibiting the use of his data for its own purposes or for those of third parties, third, disclosure concerning the use of his data and, fourth, the production of accounts and damages in respect of the variation of contract terms, harm suffered and unjustified enrichment. Mr Schrems claims to have locus standi on the basis of both his own rights and similar rights which seven other contractual partners of the defendant in the main proceedings, who are, according to the applicant, also consumers and residing in Austria, Germany or in India, have assigned to the applicant for the purposes of his action against Facebook Ireland. According to Mr Schrems, the Landesgericht für Zivilrechtssachen Wien (Regional Civil Court, Vienna) has international jurisdiction as the forum of a consumer under Article 16(1) of the Brussels I Regulation. The Landesgericht für Zivilrechtssachen Wien (Regional Civil Court, Vienna) dismissed the action brought by Mr Schrems on the ground

21 Initially, he used that social network only for personal purposes under a false name. Since 2010, he has been using a Facebook account solely for his private activities. since 2011, he has opened a Facebook page registered and established by him, in order to report to internet users on his legal proceedings against Facebook Ireland, his lectures, his participation in panel debates and his media appearances, as well as to call for the donation of funds and to publicise his books 
that, since he is also using Facebook for professional purposes, he could not rely on jurisdiction over consumer contracts. According to that court, the jurisdiction ratione personae of the assignors of claims is not transferable to the assignee.

Mr Schrems brought an appeal against the order at first instance before the Oberlandesgericht Wien (Higher Regional Court, Vienna, Austria). That court amended that order in part. It upheld the claims related to the contract concluded between the applicant in the main proceedings in his own name and the defendant in the main proceedings. By contrast, it dismissed the appeal in so far as it concerned the assigned claims on the ground that the forum of a consumer can be invoked only by an applicant relying on his own claims. Both parties brought an appeal on a point of law ('Revision') against that judgment before the Oberster Gerichtshof (Supreme Court, Austria). That court states that, if the applicant in the main proceedings were a 'consumer', the action should be brought in Vienna. The same would apply to any proceedings brought in relation to the rights of a consumer resident in Vienna. According to the referring court, there is no significant additional burden on the defendant in the main proceedings if it were to be required in the course of these proceedings also to defend itself against additional assigned claims.

The CJEU found that the activities of publishing books, lecturing, operating websites, fundraising and being assigned the claims of numerous consumers for the purpose of their enforcement do not entail the loss of a private Facebook account user's status as a 'consumer' within the meaning of Art $\mathbf{1 5}$ of Brussels I Regulation. However, according to the CJEU it is not possible for the consumer to rely on Art 16(1) of Brussels I Regulation in order to assert, in the courts of the place where he is domiciled, not only his own claims, but also claims assigned by other consumers domiciled in the same Member State, in other Member States or in non-member countries.

\section{RULES ON JURISDICTION - TERRITORIALITY V. FUNCTIONALITY}

Principle of territoriality is considered to be a traditional organizational standard according to which jurisdiction is awarded based on the geographical location of the court. It encompasses issues of timelines, hearing and understanding. Also, it contributes to accessibility, comprehensibility and visibility of the judiciary towards society. ${ }^{22}$ It is equally important in the context of national and international

22 Mak, E., Balancing Territoriality and Functionality;Specialization as a Tool for Reforming Jurisdiction in the Netherlands, France and Germany, International Journal for Court Administration, Vol. 1, No. 2, 
civil procedure litigation. However, in comparison to internal, in international dispute resolution jurisdictional issues have different function and relevance. Determining international jurisdiction is the first step that assures that dispute is resolved within one national juridical system. ${ }^{23}$ For this utmost importance, regulation of international jurisdiction was in the past perceived as purely autonomous national issue. ${ }^{24}$

Rules on jurisdiction in Brussels I Regulation (arg. ex Art 2) and Brussels I bis Regulation (arg. ex Art 4) as significant private international law instruments apply if a defendant is domiciled in a Member State. Their function is twofold, as they establish the general rule for the territorial application of the jurisdiction of the jurisdiction chapter of the Brussels I regime/Brussels I bis regime and the general rule for jurisdiction. ${ }^{25}$ The general rule, based on the territorial scope of application exists for the protection of the defendant, because it is considered that a person being sued is generally in a weaker position and should be favoured in order to compensate for the fact that he has to defend himself against the claimant's action. ${ }^{26}$ Jurisdiction should always be available on this ground, save in situations which are considered as exceptions to the general rule. ${ }^{27}$ These exceptions guarantee procedural justice and protection to weaker parties (consumers, employees and insurance policy holders) in proceedings against defendants in Member States. In example, special provisions relating to jurisdiction for disputes arising from consumer contracts (arg. ex Art 15-17 Brussels I Regulation; Art 17-19 Brussels I bis Regulation) ensure adequate protection for the consumer as the party deemed to be economically weaker and less experienced in legal matters than its counterparty. ${ }^{28}$ Although similar provisions may also be provided in the national laws of the Member State, as the legal literature observes, such rules are not necessarily identical, so that the "level of protection“ may vary among different Member States. ${ }^{29}$

In order to achieve enhanced functionality of court proceedings methods such as concentration of jurisdiction, case management, e-justice and specialization of

2008, p. 2-9, pp. 2

23 Vuković, Đ; Kunštek, E., Međunarodno građansko postupovno pravo, Zagreb, 2005

24 Župan, M.; Poretti, P., Concentration of jurisdiction in cross-border family matters - child abduction at focus, in: Vinković, M. (ed.), New developments in EU labour, equality and human rights law, Pravni fakultet Osijek, Osijek, 2015, p. 342

25 Dickinson; Lein, op. cit., note 5, p. 113

26 Ibid., p. 116. CJEU Case C-295/95 Jackie Farrell v. James Long (1997) ECR I-1683, I-1708 para. 27

27 See also Dickinson; Lein, op. cit., note 5, p. 21-22

28 CJEU, Case C-89/91Shearson Lehmann Hutton Inc. v TVB Treuhandgesellschaft für Vermögensverwaltung und Beteiligungen mbH, ECLI:EU:C:1993:15, 19 Januay 1993

29 Lazić, op. cit, note 6, p. 102 
judges are employed more often in national civil procedure litigation. Although the level of their success in increasing access to justice and efficient administration of justice in general can be observed separately, their best result is achieved when combined. Namely, concentration of jurisdiction requires providing for both infrastructure which places jurisdiction before a limited number of courts in the Member States but also for offering training to judges which enables them to conduct such proceedings in appropriate manner. Such specialized and experience judges usually deliver judgments which are appealed less frequently, thereby generating less cost and providing more legal certainty. However, in employing these measures Member States should both observe the internal structure of the legal system concerned, but also, in the context of cross-border litigating, respect the requirements of regimes provided under EU instruments on judicial cooperation in civil and commercial matters.

\section{PRINCIPLE OF TERRITORIALITY AND CONSUMER (WEAKER PARTY) PROTECTION}

In case C498/16 CJEU analysed circumstances under which it is possible to derogate form the general rule provided in Art 2(1) of the Brussels I Regulation according to which the courts of the Member State in which the defendant is domiciled have jurisdiction in the matter. Exceptions, under which the defendant may or must be sued before the courts of another Member State, are considered as derogation from that principle and are to be strictly interpreted. ${ }^{30}$ In regard to jurisdiction over consumer contracts such special provisions are provided under Articles 15 and 16 of the Brussels I Regulation and under Art 17 and 18 of the Brussels I bis Regulation. As highlighted in the legal theory, these provisions apply only to disputes between an individual consumer and his/her counterparty. ${ }^{31}$ In a similar vein, the CJEU concluded that exception provided for a consumer as a weaker party under Art 16(1) Brussels I Regulation cannot be applied to the proceedings brought by a consumer for the purpose of asserting, in the courts of the place where he is domiciled, not only his own claims, but also claims assigned by other consumers domiciled in the same Member State, in other Member States or in non-member countries. Obviously, CJEU differentiates between the position of a plaintiff as a consumer asserting his own claim and as a plaintiff to whom claims of other consumers have been assigned. One of the reasons for the CJEU not to acknowledge the 'privileged' position of the consumer in regard to the application

\footnotetext{
30 See, to that effect, CJEU, case C464/01, Gruber, EU:C:2005:32, 20 January 2005, para 32

31 Dickinson; Lein, op. cit., note 5, p. 218
} 
of the rules on jurisdiction in asserting the assigned claims, might be the fact that the assignment of a claim is a contract of lucrative nature. ${ }^{32}$

'Concentration' of several claims in the person of a single applicant discussed in this case differs from concentration of jurisdiction considered in the joined cases C-400/13 and C-408/13 or case C-498/14 PPU Bradbrooke which will be discussed in more detail later. Although it could be argued that at a certain level attempt of 'concentration of claims' in the case at hand was also aimed at enhancing functionality, it seems that CJEU did not accept such an argument.

Hence, it is interesting to try to advance arguments in both in favour and against the CJEU's approach. Respect for the Brussels I Regulation regime and the manner in which the exception provided under Art 16(1) is to be interpreted are certainly arguments in favour of the CJEU's position. Also, this restrictive interpretation reflects the position CJEU took in its earlier decisions, according to which the special head of jurisdiction in Art 16(1) Brussels I Regulation is only available personally to the consumer who is party to the consumer contract in question ${ }^{33}$, and according to which the assignment of a claim does not affect international jurisdiction under the Brussels I Regulation ${ }^{34} .{ }^{35}$ But, it could also be argued that this restrictive interpretation of the introduced exceptions to the general rules on jurisdiction does not adequately take into account the requirements of ensuring functionality or facilitated access to justice in court proceedings. Therefore, critics of the CJEU's approach caution of the interesting, but nevertheless unfortunate side effect of this restrictive interpretation. ${ }^{36}$ Namely, such interpretation of the rule under Art 16(1) Brussels I Regulation excludes the consolidation of the claims of other Austrian consumers in the same forum.

It seems that AG Bobek recognized the significance of offering a functional approach by way of providing for a common forum for resolving a large number

32 In this sense, a judgment of the Supreme Court of Croatia II Rev 117/03-2 from 16 December 2003 in which the Supreme Court decided on the necessity of the change of a claim in case of cession during the proceedings.

33 CJEU, Case C-89/91 Shearson Lehmann Hutton Inc. v TVB Treuhandgesellschaft für Vermögensverwaltung und Beteiligungen mbH, ECLI:EU:C:1993:15, 19 Januay 1993; case C-167/00 Verein für Konsumenteninformation v Karl Heinz Henkel, ECLI:EU:C:2002:555, 1 October 2002

34 Case C-352/13 Cartel Damage Claims (CDC) Hydrogen Peroxide SA v Akzo Nobel NV and others, ECLI:EU:C:2015:335, 21 May 2015

35 See Ruehl, G., Fifty Shades of (Facebook) Blue - ECJ Renders Decision on Consumer Jurisdiction and Assigned Claims in Case C-498/16 Schrems v Facebook, [http://conflictoflaws.net/2018/fifty-shades-of-facebook-blue-ecj-renders-decision-on-consumer-jurisdiction and-assigned-claims-incase-c-49816-schrems-v-facebook] Accessed 01.02.2019

36 Ibid. 
of assigned consumer claims. Hence, he proposed alternative routes for bringing claims assigned to a consumer by other 25,000 other consumers in the forum at the place of the consumer's domicile. In his opinion, since interpretation of Art 16 (1) does not provide for such a possibility, an additional forum in which such consumer claims could be brought could be created under national law (Opinion, 117). According to AG Bobek the fact that Art 16(1) of Brussels I Regulation does not establish a new special jurisdiction does not, in his view, mean that it would prevent it if it were internally provided for by national law. The logic of the local jurisdiction in Art 16(1) is that the consumer cannot be deprived of it. In any event, should an additional one be provided for under national law, within that Member State, that would, to his mind, not run counter to either the wording or the objectives of the Regulation. However, this does not seem to be the case in the present proceedings, inasmuch as the arguments of the applicant to establish jurisdiction (even within the same Member State), appear to rely exclusively on Art 16(1) of Brussels I Regulation. But, according to some authors it is questionable whether such a proposition appears easily reconcilable with the clear wording of Art 16(1). ${ }^{37}$ Namely, in interpreting Art 18(1) Brussels I bis Regulation (corresponds to text of Art 16 (1) Brussels I Regulation, with no material amendment) the legal theory points out that the provision at hand appears to regulate both international and internal jurisdiction; in other words, it does not designate the court having international jurisdiction, but also the local court's venue in the State concerned. On this basis, application of national rules on the court's venue is therefore excluded..$^{38}$

Another possibility for the claimant is to rely on the first alternative of Art 16(1) Brussels I (which mirrors Art 2(1)) and bring all claims in the defendant's Member State of domicile, the procedural law of which will then decide on whether the claims may be consolidated. This possibility is reconcilable with the meaning of Art 16(1) Brussels I Regulation. However, it fails to take into account the fact that the possibility for the court to establish jurisdiction as the court of the consumer's place of domicile (forum actoris) promotes consumer's access to justice. Namely, it could be argued that for reasons such as limited resources of the consumer, as well as the fact that the goods and services generally covered by the contract are typically (but not inevitably) of little value, it is unlikely that not only the individual consumer but 25,000 other consumers as well will bring proceedings in the foreign State of the trader's domicile (this is at least true for consumers in the State of consumer's domicile and all States other than the State of the trader's domicile). It should also be noted that the court seized at the consumer's domicile

\footnotetext{
$37 \quad$ Ibid.

38 Dickinson, op. cit, note 5, p. 232
} 
will frequently have the advantage of deciding the case on the basis of the law of the forum (arg. ex Art 6 Rome I Regulation), which is also an important factor in terms of procedural economy. ${ }^{39}$

These are all valid arguments supporting the criticism of the Court's approach insofar for applying a rather flexible interpretation to Art 15(1) Brussels I, allowing for changes of circumstances to be taken into account but also distinguishing the enforcement of (consumer) rights from other types of professional activities. At the same time, CJEU interprets the special head of jurisdiction in Art 16(1) restrictively, limiting the privilege to each individual consumer and excluding the possibility of other consumers assigning their claims to one who is domiciled in what may appear as a more favourable forum. ${ }^{40}$ In the light of the above, concerns regarding such nuanced approach of the CJEU to the special provisions for consumer contracts do not seem to be without (at least some) merit.

There is one more interesting aspect of this case, which the claimant tried to address by invoking the 'significance of consumer collective redress' argument. Undoubtedly, consumer collective redress mechanisms are important for the effective functioning of a consumer dispute resolution system. They provide an incentive to participate jointly in litigation cases, as they are a means of spreading litigation costs and risks among individuals. Also, collective redress mechanisms increase prospects of success for consumers, address the asymmetrical balance of power between the consumers and traders and contribute to procedural economy and legal certainty. ${ }^{41}$ Still, special (protective) rule under Art 16 (1) Brussels I Regulation (Art 17 Brussels I bis Regulation) does not allow consumer associations to bring preventive actions in order to prevent the use by a trader of terms deemed to be unfair in contracts with individuals under it. ${ }^{42}$ The legal theory is silent on the possibility of a representative plaintiff (claimant) as a person entitled to initiate collective redress procedures to bring such protective actions under the provision of Art 16 (1) Brussels I Regulation. However, the analogy with the interpretation in regard to the consumer associations would not allow for such a conclusion.

Hence, with no opportunity to rely on protective rules under the Brussels I Regulation, the claimant attempted to qualify national provisions which allow for the

\footnotetext{
$39 \quad$ Ibid., p. 231

40 Ruehl, op. cit, note 35

41 Benöhr, I. EU Consumer Law and Human Rights, Oxford University Press, 2013, p. 192-193; Poretti, P. Sudska zaštita prava potrošača - (naj)bolji put?, Zbornik Pravnog fakulteta Sveučilišta u Rijeci, Vol. 39, No. 1, 2018, p. 535-570.

42 Case C-413/12 Asociación de Consumidores Independientes de Castilla y León v Anuntis Segundamano Espăna SL (2013) ECLI:EU:C:2013:800, p. 49 - 50
} 
so-called objective accumulation of claims as an adequate basis for the change of international jurisdiction or creation of a second layer of jurisdiction allowing for claims of all consumers to be asserted before the court of the claimant's domicile (arg. ex 227 öZPO). The provision on objective accumulation under 227 öZPO allows different claims of one applicant against the same defendant to be heard together in the same proceedings if two conditions are met. First, the court seized should have jurisdiction for each of the individual claims, including its territorial competence. Second, it must be possible to subject each claim to the same type of proceedings. Although the claimant offered a number of interesting propositions regarding the need for collective action for the protection of consumers in the European Union, in the view of AG Bobek, powerful as they may be on the level of policy, most of those arguments rather pertain to reflections on the potential future of the law, but find limited support in the law as it stands today. In the light of the nature of the provisions on objective accumulation and the characteristics of collective redress, it is only possible to agree with AG Bobek. Namely, provisions on objective acccumulation are not intended for facilitating collective redress. They are procedural rules allowing for a number of claims to be brought by the same claimant against the same defendant. In contrast, collective redress is regulated by specific provisions, adjusted to the fact that the claimant is entitled to initiate proceedings for protection of the interest of members of the group (class). Hence, it does not seem that either Art 16(1) Brussels I Regulation or Art 227 öZPO are reconcilable with the idea of advancing collective redress. As some critics explain, although there may well be strong arguments for the existence of such a possibility, especially in cases where each individual claim is too small to justify litigation but the sum of them is not, it seems questionable whether Art 16(1) Brussels I would be the right instrument to create such a mechanism of collective redress - and, indeed, whether it should be the Court's role to implement it. ${ }^{43}$

\section{PRINCIPLE OF FUNCTIONALITY AND MAINTENANCE CREDITOR (WEAKER PARTY) PROTECTION}

Since in joined cases C-400/13 and C-408/13 the CJEU was asked to interpret Regulation No 4/2009 for the first time, in its interpretation of a general provision on jurisdiction in Art 3 of Regulation No 4/2009 according to which in matters relating to maintenance obligations in Member States, jurisdiction shall lie with the court for the place where the defendant is habitually resident (arg. ex Art 3 (a)) or the court for the place where the creditor is habitually resident (arg. ex Art 3 (b)) the CJEU made use of the criteria which have arisen from interpretation of

43 Ruehl, op. cit, note 35 
related instruments. So the starting point of the analysis of Art 3 (b) of Regulation No 4/2009 which provides for protection of the maintenance creditor, who is considered to be the weaker party in the relationship arising from a maintenance obligation and in the proceedings which may follow ${ }^{44}$ is the fact that this rule resembles to rules on jurisdiction in other legal instruments of the EU legislator.

Following the argumentation of the Advocate General which also takes into account other legal instruments which contain similar rules on jurisdiction and caselaw in relation to those other instruments, in joined cases C-400/13 and C-408/13 the CJEU takes the view that although under the current regime maintenance obligations are excluded from the scope of application of the Brussels I and Brussels I bis Regulation, still these Regulations form a significant basis for the interpretation of Art 3(b) of Regulation No 4/2009. ${ }^{45}$ This may be concluded from the wording of Art 5(2) of the Brussels Convention which states that jurisdiction in the matter lies with "the courts of the place where the maintenance creditor is domiciled or habitually resident" as well as the Preamble of the Regulation No 4/2009 which refers to the Brussels I Regulation several times and Art 68(1) which expressly states that Regulation No 4/2009 replaces the provisions of the Brussels I Regulation applicable to matters relating to maintenance obligations. ${ }^{46}$

As the law currently stands Article 1(2)(e) of the Brussels I bis (Recast) excludes maintenance obligation but although placing more weight on habitual residence than domicile, the relevant criteria for establishing jurisdiction in Articles 3(b) and (c) of the Regulation No 4/2009 follow those set out in Articles 2 and 5(2) of the Brussels I Regulation, with only one major difference: the Maintenance Regulation also sets out rules of jurisdiction for cases in which the defendant's habitual residence is in a non-Member State, and makes no reference to national law in this regard. ${ }^{47}$

In fact, as the Advocate General explains, one of the general objectives of the Regulation No 4/2009, following that established by the Brussels Convention and then by the Brussels I Regulation, is to avoid as far as possible referral to the rules of jurisdiction under national law and to facilitate the recognition of decisions in all the Member States, which is the cornerstone of the European system of judicial cooperation in civil matters. One of those special rules of jurisdiction is

\footnotetext{
44 Compare Advocate General opinion, p. 62

45 See Advocate General opinion, p. 30

46 See Advocate General opinion, p. 29, 31

47 See Dickinson. op. cit., note 5, p. 87
} 
Article 5(2) of the Brussels Convention, which is applicable to maintenance obligations, from which Article 3(b) of Regulation No 4/2009 is derived. ${ }^{48}$

In its decision the CJEU has further relied upon arguments given in judgements in Farrell, C 295/95, and Blijdenstein, C 433/01 where it has stated in the context of Article 5(2) of the Brussels Convention, that the derogation relating to the rules on jurisdiction in matters relating to maintenance obligations is intended to offer special protection to the maintenance creditor, who is regarded as the weaker party in such proceedings.

Arguments in favour of concentration of jurisdiction put forward by the EU Commission and the German government in joined cases $\underline{\mathrm{C}-400 / 13}$ and C-408/13 were scrutinized by the Advocate General. In his opinion, rule on concentration of jurisdiction in Paragraph 28(1) of the German implementation Law of 23 May 2011 on the Recovery of Maintenance in Relations with Foreign States (Auslandsunterhaltsgesetz, 'AUG') according to which if a party concerned does not have his or her habitual residence in Germany, the court which is to rule exclusively on applications in maintenance cases falling under Article 3(a) and (b) of Regulation (EC) No 4/2009 is the Amtsgericht which has jurisdiction for the seat of the Oberlandesgericht in whose area of jurisdiction the defendant or creditor has his or her habitual residence is not compatible with Art 3 (b) of Regulation 4/2009. Contrary to the view of the German Government that centralisation of jurisdiction in matters of international maintenance obligations would have a positive impact on the organisation of justice, by enabling specialised courts, with greater expertise to conduct the proceedings, the Advocate General warns against the effect that concentration might have on rules of cross-border jurisdiction laid down by EU law. Requirements of sound administration of justice include access to justice and foreseeability of jurisdiction, owing to a close link between the court and the dispute but at the same time Paragraph 28 of the AUG withdraws powers from the court which would normally have jurisdiction because it is in the place of the creditors' habitual residence, that is to say, on the basis of a close link between the forum and the dispute, although that jurisdiction remains in place for ruling on applications which are identical but which do not have a foreign aspect.

The view of the CJEU is not so straightforward as the view of the Advocate General because in delivering its decision, the CJEU took into account fundamental objectives of the Regulation No 4/2009, effective recovery of maintenance claims in cross-border situations, proper administration of justice and preservation of creditor's interests. Although the CJEU acknowledged that development of spe-

48 See Advocate General, 52 
cific expertise which centralisation of jurisdiction promotes may satisfy all three objectives of the Regulation No 4/2009, he nevertheless warned of the possible restrictive effect that centralisation might have on recovery of maintenance claims. ${ }^{49}$

\section{PRINCIPLE OF FUNCTIONALITY AND (CHILD AS A WEAKER PARTY) PROTECTION IN RETURN OR CUSTODY CASES}

In contrast, in regard to interpretation of Art 11(7) and (8) of the Brussels II bis Regulation in case C498/14 PPU David Bradbrooke v Anna Aleksandrowicz CJEU found that if there is a specialised court which examines questions of return or custody with respect to a child in the context of the procedure set out in Art 11(7) and (8) of the Regulation, even where proceedings on the substance of parental responsibility with respect to the child have already, separately, been brought before a court or tribunal, it does not impair the effectiveness of the Regulation. However, it must be ensured that such an allocation of jurisdiction is compatible with the child's fundamental rights as stated in Art 24 of the Charter and, in particular, with the objective that procedures should be expeditious.

According to Advocate General Jääskinen such a rule for the internal allocation of jurisdiction ratione materiae and for the specialisation of courts, in itself, does not impair either the effectiveness of those provisions of the Regulation or the principles and objectives which underpin them, and in particular is not necessarily contrary to the objective of expedition. The rules of Belgian law which are the subject of the request for a preliminary ruling are based on objectives which are compatible with those of the Brussels II bis Regulation. As stated by the referring court, the grounds stated for the Belgian legislation indicated that the specialisation of courts and the concentration of jurisdiction was justified by the technical nature of the court proceedings relating to international child abduction, the desire to improve the effectiveness and rapidity of action of the Belgian courts in this area, and by the intended strengthening of direct cooperation between judges and magistrates of different Member States.

In delivering his judgment, CJEU most likely placed due weight on the fact that organisation of the Member States' court system is outside the scope of the Brussels II bis Regulation. At the same time, the judgment reflects the position that due to the complexity and the nature of the matters regulated by different international instruments on child abduction, well trained and specialized judges are required. The experience of Member States in which jurisdiction under 1980 Hague Convention is concentrated on a limited number of courts and judges is positive and shows enhanced quality and ef-

49 Koutsoukou, G. Report on recent German case-law relating to Private International law in family law matters, RDIPP, p. 234 
ficiency. ${ }^{50}$ Furthermore, if judges with specialized knowledge are included in the process, the functioning of the Convention and the Brussels II bis Regulation regime in regard to child abduction and related matters concerning children is optimized. ${ }^{51}$

\section{CONCENTRATION OF JURISDICTION AS MEANS OF ENHANCING ACCESS TO JUSTICE IN CROSS-BORDER CASES UNDER EU REGULATIONS}

There is no coherent regulatory approach to weaker party protection in the European private international law of contractual and non-contractual obligations, family and succession law. Still, the comparison of the legal instruments in these fields shows that there are several (various) groups of protected weaker parties but protection of each of these groups is based on uniquely created provisions. ${ }^{52}$ Protection of consumers is provided in Article 6(2) of the Rome I Regulation, Article 14(1) of the Rome II Regulation, Article 16 and 17 of the Brussels I Regulation and Article 17 and 18 of the Brussels I bis Regulation. Passengers, (mass) insurance policy holders or beneficiaries and employees present another group of weaker parties whose protection is guaranteed in provisions on jurisdiction in Sections 3, 4 and 5 of the Brussels I Regulation. Also, protection is granted to maintenance creditors, especially minors in Articles 7 and 8 of the Hague Maintenance Protocol. On the level of international civil procedure protection Article 15 and 23 of the Brussels I recast and Article 4(3) of the Regulation No 4/2009 complement protection afforded to weaker parties, apart from consumers. ${ }^{53}$

Although from the texts of these legal instruments it remains unclear why only certain groups are afforded weaker party protection, given that there are also numerous other vulnerable groups, still legal literature has managed to define three criteria. First, vulnerability is attributed to the lack of information or information asymmetries between parties, especially consumers, employees, (mass) insurance policy-holders or beneficiaries. Namely, the cost of acquiring information is much higher than its benefit. ${ }^{54}$ As economically or socially dependent parties mainte-

50 Practice Guide for the application of the Brussels IIa, Directorate General for Justice (European Commission), 2016, p. 50

51 Ibid. For the details on International Hague Judicial Network see [http://www.hcch.net/index_ en.php?act=text.display\&tid=21] Accessed 12.02.2019. European Network on Family Law Judges is a part of European Judicial Network in civil matters

52 Rühl, G. The protection of Weaker Parties in the Private International of the European Union: A Portrait of Inconsistency and Conceptual Truancy, Journal of Private International Law, Vol. 10, 2014, pp. 335-358, p. 340

53 Ibid., p. 340-342; Lazić, op. cit., note 6, p. 102-103

54 Ibid., p. 344-345 
nance creditors, especially minors and employees are also perceived as weaker parties. This is emphasized in situation where a maintenance creditor is a minor and the debtor is his family member. ${ }^{55}$ Finally, mental or intellectual disadvantage may also be considered to be a source of vulnerability.

However, if rules on jurisdiction under Brussels I or Brussels I bis Regulation regime are compared to EU instruments that unify certain rules of civil procedure, it is important to notice that they do not have the same level of consistency in approach towards the regulation of rules on jurisdiction for weaker party protection in proceedings.

In EEO Regulation certification of the judgement as European Enforcement Order is conditioned by compliance with rules on jurisdiction in Regulation No 44/2001 (arg. ex Art. 6 (b), 3(1) (a) and (d)). Similar requirements are prescribed in Art. 6 of the European Order for Payment Procedure. Consumer may only be sued in the courts of its domicile (arg. ex 6(2)) wherein domicile is to be determined in accordance with the Brussels I Regulation. If these requirements regarding jurisdiction are not met, an application for a European Order for Payment shall not be granted (arg. ex Art 11(a)).$^{56}$ However, protection of the weaker party in proceedings and the requirement for the court in the Member State of origin to respect certain jurisdictional rules in proceedings regarding weaker parties is not included in the wording of Regulation No 861/2007. At the same time, Art 25 of the Regulation No 861/2007 explicitly prescribes a possibility of concentration of jurisdiction. On the one hand, some legal scholars were of the view that recent developments in the field of international civil procedure and in particular, Commission's Proposal on revision of the Regulation No 861/2007 (resulting in the amending Regulation 2015/2421) brought further harmonisation and incorporated protection of weaker parties, in the same or a similar manner, in different EU legal instruments regulating certain aspects of international civil procedure. ${ }^{57}$ On the other hand, as observed, there is a certain trend of abandoning rules on jurisdiction based on the principle of territoriality and opting for the concentration of jurisdiction based on the principle of functionality. Namely, according to the EU Commission interpretation of the Regulation 1896/2006 on the European Order for Payment Procedure (EOP), concentration of jurisdiction is also applicable in European Order for Payment Procedure. As the (non-public) minutes of a meeting on the implementation of the EOP-regulation show, this was a view

\footnotetext{
55 Ibid.

56 See Lazić, op. cit., note 6, p. 115-116

57 Ibid., p. 116.
} 
which EU Commission communicated in December 2008. Recent development in Dutch law shows that Member States are making use of the possibility. ${ }^{58}$

Since the discrepancy in rules on jurisdiction may be interpreted as a gradual shift towards principle of functionality, it is necessary to examine whether concentration of jurisdiction which is usually employed in such cases is means for realization of the principle of functionality and enhancing access to justice.

Concentration of jurisdiction may be defined as a mechanism through which one or more courts in specific territories on the basis of legal provisions or through agreements between courts are allocated exclusive competence to deal with certain categories of cases. ${ }^{59}$ In terms of contributing to functionality of the court proceedings, crucial advantage of concentration of jurisdiction is a possibility to access specialized courts which have the necessary expertise in litigation of great factual and legal complexity. Indeed, legal literature perceives concentration of jurisdiction as one of several forms of specialization ${ }^{60}$. Other benefit of concentration of jurisdiction is the fact that by concentrating similar cases both quality and timeliness of decision making as well as legal certainty is improved. ${ }^{61}$ The main disadvantage is different geographical remit of the courts which requires the creditor to travel further. However, legal instruments which provide for concentration of jurisdiction generally prescribe the use of modern communications technologies in order to facilitate taking of evidence and oral hearing, so that additional burden is not placed on the creditor. ${ }^{62}$

In the EU Commission Report on the application of Regulation (EC) No 861/2007 on ESCP the Commission points out that while specialization of judges and courts may be regarded as advantage of concentration of jurisdiction, at the same time, once again, the disadvantages of concentration in terms of geographical distance and increased cost of the procedure are meant to be overcome by use of electronic processing of cases and distance means of communication. ${ }^{63}$ Similar arguments were introduced in the Dutch Proposal of amendments to the Implementation Act on Regulation (EC) No 1896/2006 creating a European order for payment procedure from 24 February 2015. Namely, it provides for applications for a European order for payment to be lodged with (exclusively) the District Court of The Hague (civil-law section). Introduction of the rule on concentration

See infra.

59 Hartendorp, R. C. Notitie rechterlijke concentratie, Raad voor de rechtspraak, 2003

60 The other two forms are allocation and cooperation. Mak, op. cit., note 22, p. 2

${ }_{61}$ Ibid., p. 3

62 Recital 20 of Preamble Regulation No 861/2007

63 See EU Commission Report on the application of Regulation (EC) No 861/2007 on ESCP 
of jurisdiction should contribute to simplification of litigation for (foreign) claimants, since they no longer have to establish which court has jurisdiction to issue a European enforcement order. It is submitted that the Proposal makes it easier for foreign claimants to manage cross-border debt collection. ${ }^{64}$

In the context of the posed question, it is significant to point out that the Regulation No 861/2007 as the only legal instrument on unified European civil procedure which (directly) prescribes concentration of jurisdiction was also introduced with the aim of facilitating access to justice and removing imbalances with regard to the functioning of the procedural means afforded to creditors in different Member States. According to the Recital (9) of the Preamble Regulation No 861/2007 seeks to promote fundamental rights and takes into account, in particular, the principles recognised by the Charter of Fundamental Rights of the European Union. The court or tribunal should respect the right to a fair trial and the principle of an adversarial process, in particular when deciding on the necessity of an oral hearing and on the means of taking evidence and the extent to which evidence is to be taken. ${ }^{65}$

It seems that the underlying principle of the decision the CJEU delivered in joined cases C-400/13 and C-408/13 is that regardless of the nature and the source from which the rule on jurisdiction derives (the fact that in concreto Article 3(b) of Regulation No 4/2009 should be understood as precluding national legislation such as that at issue in the main proceedings which establishes a centralisation of judicial jurisdiction in matters relating to cross-border maintenance obligations in favour of a first instance court which has jurisdiction for the seat of the appeal court), in cross-border maintenance obligations cases preference should be given to rules on jurisdiction which in the best possible manner facilitate access to justice and sound administration of justice. Even if it means that the rule which precludes national legislation such as that at issue in joined cases C-400/13 and C-408/13 should be disregarded.

A similar point was used by the CJEU to justify its judgement in C498/14 PPU David Bradbrooke v Anna Aleksandrowicz. According to the CJEU, in order for the specialization of courts and concentration of jurisdiction provided by Belgian legislation to be compatible with the objectives of the Brussels II bis Regulation, it must be ensured that such an allocation of jurisdiction is compatible with the child's fundamental rights as stated in Art 24 of the Charter and, in particular, with the objective that procedures should be expeditious. It seems that again, CJEU accepts rules for the internal allocation of jurisdiction ratione materiae and for the specialisation

\footnotetext{
64 Concentration of jurisdiction (NL) EOP- procedure, [http://uk.banning.nl/publications/detail. html/24178/concentration-of-jurisdiction-nl-eop-procedure] Accessed 16.01.2019

65 Recital 7-9 of Preamble Regulation No 861/2007
} 
of courts, provided that such rules enhance access to justice and help achieve sound administration of justice.

Apparently, under certain conditions ${ }^{66}$, CJEU is willing to set aside the underlying idea that the Brussels II bis Regulation regime as well as regimes under other Regulations provide for a compete and closed set of jurisdiction rules, designated to grant jurisdiction to the court best qualified to ensure respect for the best interest of the child and/or sound administration of justice'. ${ }^{67}$ In both cases analysed above CJEU considered application of national rules providing for concentration of jurisdiction as valid justification for such a choice.

All of the above implies that concentration of jurisdiction may be relevant in the context of considerations on the future developments and application of legal instruments of private international law and civil procedure. Distinction can be made between legal instruments based on their protective aim and purpose, which requires the traditional rules of jurisdiction to be abandoned and rules on concentration of jurisdiction to be integrated in order to facilitate access to justice. Thereby, the first group consists of legal instruments of private international law and civil procedure in the field of cross-border civil and commercial matters which provide protection of economic interest of the parties (Brussels I bis Regulation, Regulation 1896/2006, Regulation No 861/2007, Regulation No 805/2004). The second group covers legal instruments of private international law in the field of cross-border family law matters whose specific nature requires special social protection (Maintenance Regulation, Brussels II bis Regulation).

In cross-border consumer cases concentration of jurisdiction enables a plaintiff to detect in advance which court of the Member State has jurisdiction in the dispute, it provides for cost-effective proceedings and more legal certainty. In cross-border family law matters concentration of jurisdiction which enables specialised courts

66 As AG Bobek explained in C498/14 PPU David Bradbrooke v Anna Aleksandrowicz 'as stated by the Belgian Government and by the Commission, such an approach is consistent with the recommendations, in favour of a concentration of international child abduction cases in a restricted number of courts, which are made in the guides produced within the European Union and by the Hague Conference on international private law. It seems to me important to maintain the systems for the specialisation of courts which have been identified as constituting 'best practice' in that connection, since the 1980 Hague Convention remains applicable as such between the Member States even though it is complemented by the Brussels II bis Regulation. I am therefore of the opinion that the provisions of the Brussels II bis Regulation do not, per se, preclude a Member State from choosing the specialisation of courts with jurisdiction to rule on the substance of the matter in situations where a child has been wrongfully removed or retained. It is not apparent that such specialisation presents any difficulty if a single set of proceedings concerning the custody of the child is commenced at the request of the parties'

${ }_{67}$ See as example Recital 12, 13 of the Preamble Brussels II bis Regulation, Recital 15 Recital of the Preamble Maintenance Regulation, Recital 16 of Preamble Brussels I Regulation 
with greater expertise to conduct the proceedings is especially relevant in cases involving children and minors. But at the same time geographical distance and increased cost of the proceedings does not seem to facilitate access to justice to children and minors (as weaker parties).

In cross-border consumer cases traditional rule on jurisdiction based on the principle of territoriality enables access to court without the use of modern technologies and it is still more adequate for national systems of Member States which do not have necessary IT infrastructure (i.e. Croatia). In comparison, traditional rule based on territoriality was introduced in Maintenance Regulation in order to ensure that the creditor may bring proceedings without too much financial difficulty as a result of journeys, but also that he may assert his rights before a court which is the best placed to be aware of particular local economic circumstances, in order to establish the creditor's resources and needs and, accordingly, the maintenance debtor's ability to contribute to them. ${ }^{68}$

\section{CONCLUSION}

As the analysis shows, there is no easy solution or a single answer to the question if enhancing functionality through concentration of jurisdiction will eventually become an advantage or obstacle to access to justice.

This recent development in the jurisprudence of the CJEU may be interpreted in a way that although rules on jurisdiction provided in EU Regulations were created in order to harmonize rules on jurisdiction and facilitate access to justice, supremacy of the rules of jurisdiction under EU Regulations, such as that at issue in Maintenance or Brussels II bis Regulation, is not absolute and under certain conditions it may be put aside. However, these conditions should be interpret restrictively and be limited to situations where national rules on jurisdiction enhance effectiveness and efficiency of administration of justice in a superior manner to the rules of jurisdiction provided in EU Regulations. It remains to be seen whether national courts will try to use this caveat as means of avoiding or circumventing application of the rules of jurisdiction under the EU Regulations even in situations where these conditions have not been met.

It should also be kept in mind that concentration of jurisdiction as a new approach towards the regulation of jurisdiction which introduces 'management principles' ${ }^{69}$ in comparison to the traditional rule on jurisdiction based on the principle of territoriality in some cases may have a negative effect, as it might deteriorate tradi-

\footnotetext{
$68 \quad$ See Advocate General opinion, p. 49

69 See Mak, op. cit., note 22, p. 4
} 
tional principles of judicial independence and impartiality. Also, new „strategies“ in facilitating access to justice by means of modern technologies might be considered as advantage in comparison to "classical“ ways of approaching the court only if there are adequate resources for employing these strategies. So, it can be said that both approaches at the same time complete and supplement and also contradict each other in facilitating access to justice.

\section{REFERENCES}

\section{BOOKS AND ARTICLES}

1. Benöhr, I. EU Consumer Law and Human Rights, Oxford University Press, 2013, p. 192-193

2. Dickinson, A.; Lein, E. The Brussels I Regulation Recast, Oxford University Press, 2015

3. Hartendorp, R. C. Notitie rechterlijke concentratie, Raad voor de rechtspraak, 2003

4. Koutsoukou, G. Report on recent German case-law relating to Private International law in family law matters, RDIPP, p. 234

5. Lazić, V., Procedural Position of a 'Weaker Party in the Regulation Brussels I bis, in: Lazić, V.; Stuij, S. (eds.), Brussels I bis Regulation. Changess and Challenges of the Renewed Procedural Scheme, Springer, 2017

6. Mak, E., Balancing Territoriality and Functionality;Specialization as a Tool for Reforming Jurisdiction in the Netherlands, France and Germany, International Journal for Court Administration, Vol. 1, No. 2, 2008, p. 2-9

7. Poretti, P. Sudska zaštita prava potrošača - (naj)bolji put?, Zbornik Pravnog fakulteta Sveučilišta u Rijeci, Vol. 39, No. 1, 2018, p. 535-570

8. Rühl, G., The protection of Weaker Parties in the Private International of the European Union: A Portrait of Inconsistency and Conceptual Truancy, Journal of Private International Law, Vol. 10, 2014, p. 335-358

9. Triva, S.; Dika, M. Gradansko parnično procesno pravo, Narodne novine, 2004

10. Vuković, Đ; Kunštek, E. Medunarodno gradansko postupovno pravo, Zagreb, 2005

11. Župan, M.; Poretti, P., Concentration of jurisdiction in cross-border family matters - child abduction at focus, in: Vinković, M. (ed.), New developments in EU labour, equality and human rights law, Pravni fakultet Osijek, Osijek, 2015

12. Practice Guide for the application of the Brussels IIa, Directorate General for Justice (European Commission), 2016

\section{COURT OF JUSTICE OF THE EUROPEAN UNION}

1. Case C-413/12 Asociación de Consumidores Independientes de Castilla y León v Anuntis Segundamano Espăna SL (2013) ECLI:EU:C:2013:800

2. Case C-498/16, Maximilian Schrems v Facebook Ireland Limited, ECLI:EU:C:2018:37, 25 January 2018

3. Case C498/14 PPU David Bradbrooke v Anna Aleksandrowicz, ECLI:EU:C:2015:3, 9 January 2015 
4. Case C-89/91Shearson Lehmann Hutton Inc. v TVB Treuhandgesellschaft für Vermögensverwaltung und Beteiligungen mbH, ECLI:EU:C:1993:15, 19 Januay 1993.

5. Case C-167/00 Verein für Konsumenteninformation v Karl Heinz Henkel, ECLI:EU:C:2002:555, 1 October 2002

6. Case C464/01, Gruber, EU:C:2005:32, 20 January 2005

\section{EU LAW}

1. Council Regulation (EC) No 44/2001 of 22 December 2000 on jurisdiction and the recognition and enforcement of judgments in civil and commercial matters, OJ L 12, 16.1.2001

2. Council Regulation (EC) No 2201/2003 of 27 November 2003 concerning jurisdiction and the recognition and enforcement of judgments in matrimonial matters and the matters of parental responsibility, repealing Regulation (EC) No 1347/2000, OJ L 338/1, 23.12.2003

3. Regulation (EU) $1215 / 2012$ of the European Parliament and of the Council of 12 December 2012 on jurisdiction and the recognition and enforcement of judgments in civil and commercial matters, OJ L 351, 20.12.2012

4. Regulation (EC) No 1896/2006 of the European Parliament and of the Council of 12 December 2006 creating a European order for payment procedure, [2006] OJ L 399/1

5. Regulation (EC) No 861/2007 of the European Parliament and of the Council of 11 July 2007 establishing a European small claims procedure, [2007] OJ L 199/1

6. Regulation (EU) 2015/2421 of the European Parliament and of the Council of 16 December 2015 amending Regulation (EC) No 861/2007 establishing a European Small Claims Procedure and Regulation (EC) No 1896/2006 creating a European order for payment procedure, [2015] OJ L 341/1

7. Regulation (EC) No 805/2004 of the European Parliament and of the Council of 21 April 2004 creating a European Enforcement Order for uncontested claims [2004] OJ L 143

8. Regulation (EC) No 4/2009 of 18 December 2008 on jurisdiction, applicable law, recognition and enforcement of decisions and cooperation in matters relating to maintenance obligations, OJ L 7, 10.1.2009

\section{LIST OF NATIONAL REGULATIONS, ACTS AND COURT DECISIONS}

1. Supreme Court of Croatia II Rev 117/03-2 from 16 December 2003 in which the Supreme Court decided on the necessity of the change of a claim in case of cession during the proceedings

\section{WEBSITE REFERENCES}

1. Concentration of jurisdiction (NL) EOP- procedure, [http://uk.banning.nl/publications/ detail.html/24178/concentration-of-jurisdiction-nl-eop-procedure] Accessed 16.01.2019

2. Ruehl, G., Fifty Shades of (Facebook) Blue - ECJ Renders Decision on Consumer Jurisdiction and Assigned Claims in Case C-498/16 Schrems v Facebook, [http://conflictoflaws.net/2018/ fifty-shades-of-facebook-blue-ecj-renders-decision-on-consumer-jurisdiction and-assignedclaims-in-case-c-49816-schrems-v-facebook] Accessed 01.02.2019 